Article

\title{
Study of Lignin Extracted from Rubberwood Using Microwave Assisted Technology for Fuel Additive
}

\author{
Trakarn Yimtrakarn $^{1}$ (D), Watchareeya Kaveevivitchai ${ }^{2}\left(\mathbb{D}\right.$, Wen-Chien Lee $^{3}$ and Nuttapol Lerkkasemsan ${ }^{1, *}$ \\ 1 Department of Chemical Engineering, School of Engineering, King Mongkut's Institute of Technology \\ Ladkrabang, Ladkrabang, Bangkok 10520, Thailand; 63601052@kmitl.ac.th \\ 2 Department of Chemical Engineering, National Cheng Kung University, Tainan City 70101, Taiwan; \\ wkaveechai@mail.ncku.edu.tw \\ 3 Department of Chemical Engineering, Systems Biology and Tissue Engineering Research Center, \\ National Chung Cheng University, Chiayi 621, Taiwan; chmwcl@ccu.edu.tw \\ * Correspondence: nuttapol.le@kmitl.ac.th
}

check for

updates

Citation: Yimtrakarn, $\mathrm{T}$.

Kaveevivitchai, W.; Lee, W.-C.; Lerkkasemsan, N. Study of Lignin Extracted from Rubberwood Using Microwave Assisted Technology for Fuel Additive. Polymers 2022, 14, 814. https://doi.org/10.3390/ polym14040814

Academic Editors: Oihana Gordobil, Stefan Beisl and René Herrera Díaz

Received: 29 November 2021

Accepted: 27 January 2022

Published: 20 February 2022

Publisher's Note: MDPI stays neutral with regard to jurisdictional claims in published maps and institutional affiliations.

Copyright: (C) 2022 by the authors. Licensee MDPI, Basel, Switzerland. This article is an open access article distributed under the terms and conditions of the Creative Commons Attribution (CC BY) license (https:// creativecommons.org/licenses/by/ $4.0 /)$.

\begin{abstract}
Lignin is the most abundant natural aromatic polymer, especially in plant biomass. Ligninderived phenolic compounds can be processed into high-value liquid fuel. This study aimed to determine the yield of lignin by the microwave-assisted solvent extraction method and to characterize some essential properties of the extracted lignin. Rubberwood sawdust (Hevea brasiliensis) was extracted for lignin with an organic-based solvent, either ethanol or isopropanol, in a microwave oven operating at $2450 \mathrm{MHz}$. Two levels of power of microwave, $100 \mathrm{~W}$ and $200 \mathrm{~W}$, were tested as well as five extraction times $(5,10,15,20,25$, and $30 \mathrm{~min})$. The extracted lignin was characterized by Klason lignin, Fourier transform infrared spectroscopy (FT-IR), 2D HSQC NMR, Ultraviolet-visible spectrophotometry (UV-vis), and Bomb calorimeter. The results showed that the yield of extracted lignin increased with the extraction time and power of the microwave. In addition, the extraction yield with ethanol was higher than the yield with isopropanol. The highest yield was $6.26 \mathrm{wt} . \%$, with ethanol, 30 min extraction time, and $200 \mathrm{~W}$ microwave power.
\end{abstract}

Keywords: delignification; biomass deconstruction; microwave

\section{Introduction}

Industrial technology is rapidly depleting limited fossil fuels. For this reason, renewable energy is becoming an important alternative [1]. Lignin has received a lot of attention for its various applications, for example, dispersant [2-4], protective UV-absorbent [5,6], (nano)composite $[7,8]$, and nanoparticle $[9,10]$. In particular, there is valorization of lignin as a value added product, a lignin nanoparticle can transform to highly fluorescent graphene quantum dots [11]. Due to the complexity of the lignin structure, the pretreatment process to extract lignin from biomass is an important part of the whole extraction process. Usage of a lignin extracted by a particular method requires characterization for it to suit a particular application [12]. Currently, numerous technologies for producing lignin have received increasing attention, such as supercritical solvent extraction, hydrogenolysis, oxidation, acid hydrotropic fractionation, and solvolysis [13-17].

Lignin extraction from biomass can be carried out by a chemical delignification method, using either aqueous or organic solvent [18]. Alcohols are the most widely used organic solvent for delignification $[19,20]$. Ethanol and isopropanol were selected as the extraction solvents in this experiment because they were eco-friendly, less hazardous, easy to recover, and easily diffused into the wood [21]. A previous study by Chutikan Inkrod et al. [22] also extracted lignin from low-cost Para rubberwood sawdust like ours and achieved a $20 \%$ extraction efficiency at $160^{\circ} \mathrm{C}$ with a ternary solvent (MBK, ethanol, and water) without any catalyst. Another group of researchers, Ahmad Adlie Shamsuri and Dzulkefly Kuang Abdullah, successfully extracted lignin from rubberwood by ionic liquid. The optimum 
conditions were ionic liquid 0.5 moles, $120 \mathrm{~min}$ of extraction time, and $100^{\circ} \mathrm{C}$ temperature, which provided 13.03 wt.\% yield.

Microwave technology is an alternative biomass heating method. Microwave radiates electromagnetic energy directly generates heat inside a material. In contrast, other methods generate heat by conduction. This technique can reduce extraction time, increase the yield of a product, save energy, and create uniform heat distribution [23]. The use of microwave and ethanol to successfully extract polyphenol from grape peel by YU Hai-bo et al. [24] was similar to our use of ethanol and microwave to extract lignin from sawdust. Some of the benefits of that technique were shorter extraction time, prevention of polyphenol oxidation, and increasing polyphenol yield, which we would also like our technique to provide. The benefit of shorter extraction time when the extraction is assisted by microwave was also reported by Saksit Imman et al. [25]. The team extracted lignin contained in rice straw by microwave-assisted solvolysis method and found that microwave treatment appeared to provide a higher reaction rate and shorter reaction time with more uniform heat distribution. Long Zhou et al. [26] concluded that the microwave heating method receives a higher yield and purity of lignin compared with a conventional method. That conclusion was also supported by a previous study [27].

This study investigated the extraction of lignin from sawwood dust by microwaveassisted solvolysis with ethanol and propanol. As a part of the investigation, the extracted lignin from rubberwood was characterized. The ultimate goal for this investigation was to replace difficult-to-recover acidic or alkaline solvents with ethanol or propanol that were much safer and easier to recover.

\section{Materials and Methods}

\subsection{Materials}

Rubberwood sawdust was provided by a local wood mill in (Sri Incense (Thailand) Co., Ltd., Bangkok, Thailand) Thailand. Rubberwood sawdust was kept in the oven at $105{ }^{\circ} \mathrm{C}$ for $24 \mathrm{~h}$ for drying. Then, the material was kept in a beaker with a plastic seal to avoid moisture until needed for the experiment. Ethanol (95\%) and isopropanol (99.8\%) were from Chemipan, Bangkok, Thailand. Sulfuric acid (95-97\%) was obtained from Merck (Bankok, Thailand).

\subsection{Solvent Extraction with Microwave-Assisted Method}

The lignin extraction from the biomass process was carried out in a $500 \mathrm{~mL}$ Erlenmeyer flask. The dried rubberwood sawdust $5 \mathrm{~g}$ (solid-to-liquid ratio of 1:10 by weight) was mixed with ethanol or isopropanol prepared in room conditions. The flask was shaken and set up with a modified microwave (SAMSUNG GE711K/XST Microwave, Thai Samsung Electronics Co., Ltd., Bangkok, Thailand) (750 W, 20 L, 2450 MHz)) (Figure 1). The condenser was closed with a plastic seal. The solvent extraction was performed in the microwave oven at the power of microwave $(100 \mathrm{~W}$ and $200 \mathrm{~W})$ and extraction time (5-30 min with 5 min increments). Then, the solid fraction was separated from the mixture by vacuum filtration. The solid residue was dried in the oven at $105^{\circ} \mathrm{C}$ within the Petri dish. The liquid solution was collected for further characterization and quantitation.

\subsection{Klason Lignin Analytical Method}

Then, $1 \mathrm{~g}$ of dried wood was hydrolyzed by $15 \mathrm{~mL}$ of $72 \%$ sulfuric acid and stirred with a glass rod. After the specimen dispersion, the beaker was covered with a watch glass and kept in a water bath for $2 \mathrm{~h}$. Then, 300-400 mL of water was added into a $1000 \mathrm{~mL}$ flask. The material in the beaker was conducted to the flask. The solution was diluted by rinse water to fill a total volume of $575 \mathrm{~mL}$. The solution was boiled in the reflux system to maintain its volume for $4 \mathrm{~h}$. Lignin was precipitated by keeping the flask at the inclined position for $12 \mathrm{~h}$. Then, the solution was filtrated by vacuum filtration and washed acid remaining in precipitated lignin by using hot water. The filtration paper with lignin was 
kept in the oven at $105^{\circ} \mathrm{C}$ for $24 \mathrm{~h}$ [28]. Finally, the lignin in the dried wood (Klason lignin) was calculated by Equation (1):

$$
\text { Lignin } \%=A \times 100 / W
$$

where

Lignin $\%=$ lignin content in the wood sample

$A=$ weight of lignin, $\mathrm{g}$

$W=$ dry weight of test specimen, $\mathrm{g}$

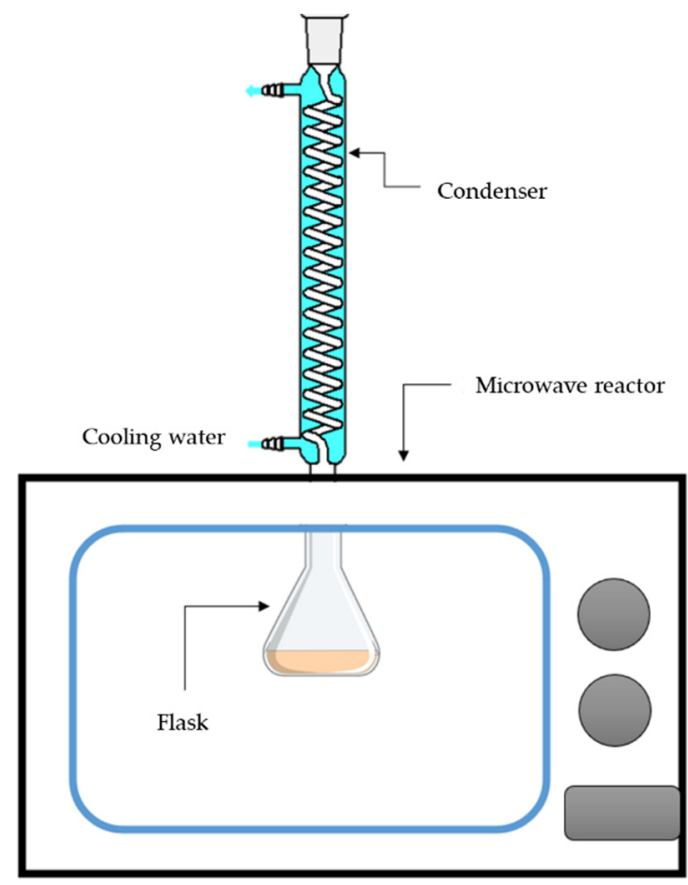

Figure 1. Schematic of the modified microwave oven.

\subsection{Ultraviolet-Visible Spectrophotometry (UV-vis) Analytical Method}

In the UV-visible spectrophotometer analysis, the solution samples were analyzed using a UV-visible spectrophotometer (Thermo Evolution 201, Madison, WI, USA). First, $0.3 \mathrm{~mL}$ of lignin sample was dissolved in $2.7 \mathrm{~mL} 95 \% \mathrm{v} / v$ ethanol in a quartz cuvette. Then, the sample absorbance was recorded at the wavelength of $200-400 \mathrm{~nm}$. The weight of extracted lignin was determined by a UV-visible spectrophotometer compared with a standard curve. The yield of extracted lignin was compared with the total lignin contained in rubberwood from the Klason method (0.02064 $\mathrm{g}$ of lignin/g of rubberwood sawdust).

The yield percentage of extracted lignin is calculated by Equation (2):

$$
\text { Yield }_{\text {Lignin }}=\frac{W_{\text {ExtractedLignin }}}{W_{\text {TotalLignin }}} \times 100 \%
$$

where

$W_{\text {ExtractedLignin }}=$ weight of lignin extracted, $\mathrm{g}$

$W_{\text {TotalLignin }}=$ weight of lignin present in the feedstock, $\mathrm{g}$

\subsection{Fourier Transform Infrared Spectroscopy (FT-IR) Characterization Method}

The prepared sample was inspected by the ATR technique. FT-IR data that were analyzed from Sci-Ins, King Mongkut's Institute of Technology, Ladkrabang, were measured on the FT-IR Spectrometer (Nicolet iS20, Madison, WI, USA). The data were recorded with a $4 \mathrm{~cm}^{-1}$ spectral resolution and a range of 4000 to $700 \mathrm{~cm}^{-1}$. 


\subsection{D HSQC NMR Characterization Method}

An amount of either $40 \mathrm{mg}$ or $0.6 \mathrm{~mL}$ of all samples was dissolved in $0.5 \mathrm{~mL}$ of methanol- $\mathrm{d}_{4}$. NMR spectra were collected by NMR spectroscopy (JEOL JNM-ECZR $500 \mathrm{MHz}$, Tokyo, Japan), which was analyzed from Sci-Ins, King Mongkut's Institute of Technology, Ladkrabang. The spectral widths were $6 \mathrm{ppm}$ and $100 \mathrm{ppm}$ for the ${ }^{1} \mathrm{H}$ - and ${ }^{13} \mathrm{C}$-dimensions, respectively. A dimension size consisting of $256 \times 819$ points was obtained in 8 scans with a $0.164 \mathrm{~s}$ acquisition time and $1 \mathrm{~s}$ relaxation delay. The ${ }^{1} \mathrm{~J}_{\mathrm{CH}}$ used constantly was $145 \mathrm{~Hz}$.

\subsection{Bomb Calorimeter Characterization Method}

For the Bomb calorimeter analysis, $20-50 \mathrm{~mL}$ of extracted solution was prepared in a stainless-steel vessel with oxygen supplied. The vessel containing the solution sample was inserted into the calorimeter, with temperatures ranging from $18{ }^{\circ} \mathrm{C}$ to $24{ }^{\circ} \mathrm{C}$. The higher heating value (HHV) that was analyzed from STREC, Chulalongkorn University was measured on the LECO AC500 Isoperibol calorimeter.

\section{Results and Discussion}

\subsection{Microwave-Assisted Extraction of Lignin}

Figure 2 illustrates the percent yield of lignin recovered from deconstructed biomass in a microwave oven using various solvents and microwave power parameters. When isopropanol was used as the solvent, the lowest percent yield of extracted lignin was observed. Lignin has a poor capacity for solubility in isopropanol. With a faster rate of delignification, ethanol is more effective than isopropanol. Even at $100 \mathrm{~W}$, ethanol had more extracted lignin, because primary alcohols are more selective than secondary and ternary alcohols in delignification [29]. Furthermore, ethanol has a lower molecular weight, which leads to greater permeability and fluidity [19]. The hydroxyl group in alcohols has nucleophilic reactive capabilities. The glycosidic bond in cellulose and the ether bond in lignin can both be decomposed by alcohol [30]. The highest lignin concentration was found when the microwave power was set to $200 \mathrm{~W}$ for $30 \mathrm{~min}$, and ethanol was used as the solvent. Furthermore, isopropanol produced a poor yield of extracted lignin, with a maximum yield of only 2.72 percent, whereas ethanol produced a yield of 6.26 percent under the same conditions. Although isopropanol may reach a higher maximum temperature in the microwave than ethanol, its solubility capacity has a greater impact.

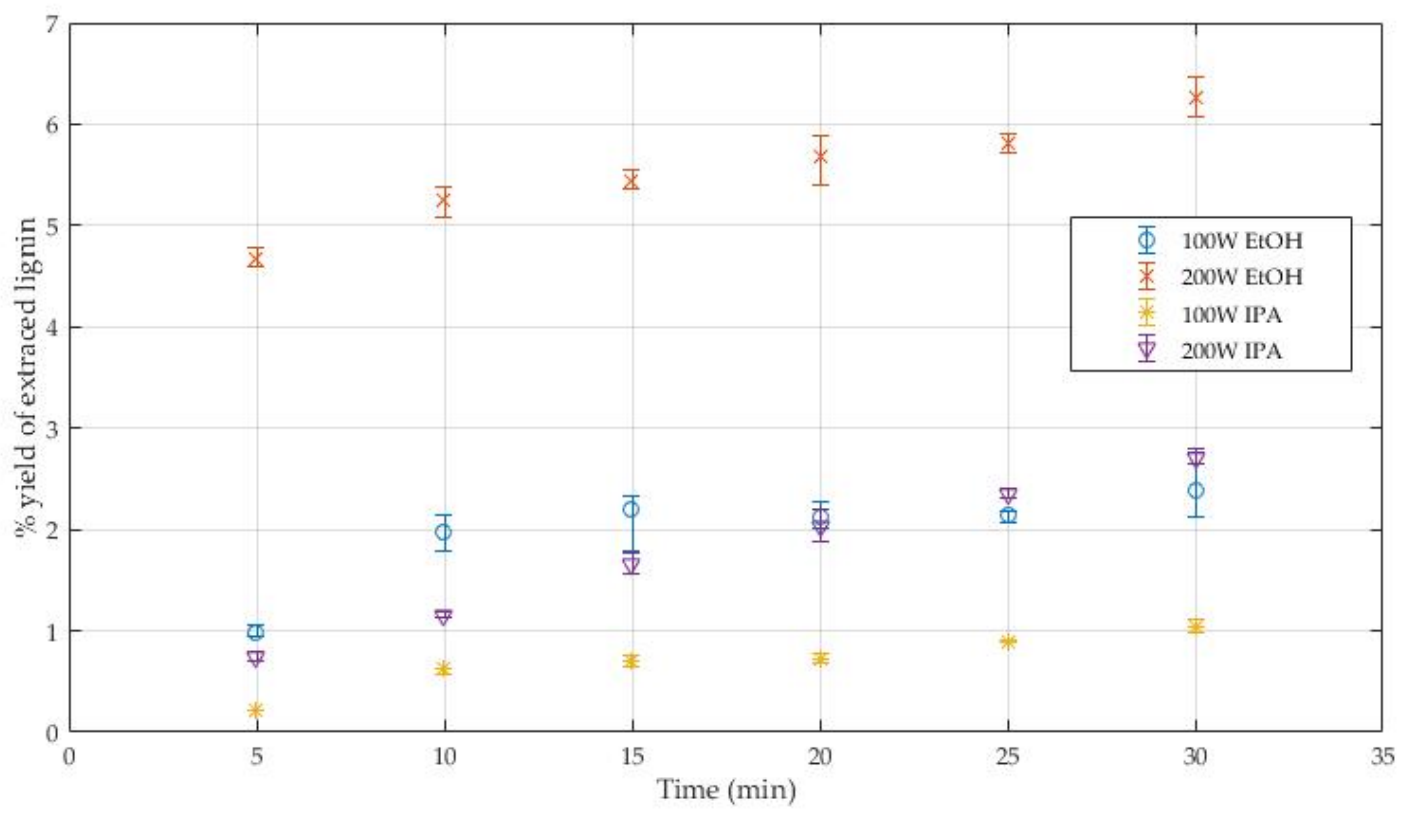

Figure 2. Percent yield of extracted lignin. 
The operational power is a direct temperature response. Microwave power influences a solvent's boiling point. Low-boiling-point solvents include ethanol and isopropanol. The boiling point of water can exceed that of the atmosphere during microwave extraction [31]. The boiling point of ethanol $20 \mathrm{~mL}$ reached roughly 12 kelvins during microwave operation at $100 \mathrm{~W}$, according to Farid Chemat and Erik Esveld [31]. The solubility of most substances increases as the temperature rises. As microwave power is increased, lignin solubility in the solvent increases. Furthermore, increasing the temperature reduces the viscosity of the alcohol solvent and improves its diffusivity. It encourages effective lignocellulose-solvent interaction. As a result, increasing the microwave power increases the lignin yields [32]. Microwave power was increased from $100 \mathrm{~W}$ to $200 \mathrm{~W}$, which resulted in a lignin production from 2.38 percent to 6.26 percent in ethanol solvent after $30 \mathrm{~min}$. At the same duration, the yield of lignin in isopropanol increased from 1.05 to 2.72 percent. The effect of extracted duration is that at short, extracted times ( $5 \mathrm{~min}$ ), the yield of lignin is low because the reaction temperature is low. This time is insufficient to break the strong bond between lignin and the other component. As a result, with increasing time, lignin yield and biomass depolymerization efficiency improve. This method less extracted lignin than the organosolv method. Nevertheless, the microwave-assisted method in this method cannot be operated with a higher power due to the solvent evaporating too rapidly to reflux. However, using the organosolv technique to remove lignin results in waste from the acid or alkaline catalyst. The absence of acid or alkaline catalysts during processing is a benefit of another technique.

\subsection{FT-IR Analytical Method}

The complete results are shown in Figure 3 and Table 1. The FT-IR spectra of products are compared with the commercial organosolv lignin and Klason lignin from rubberwood.

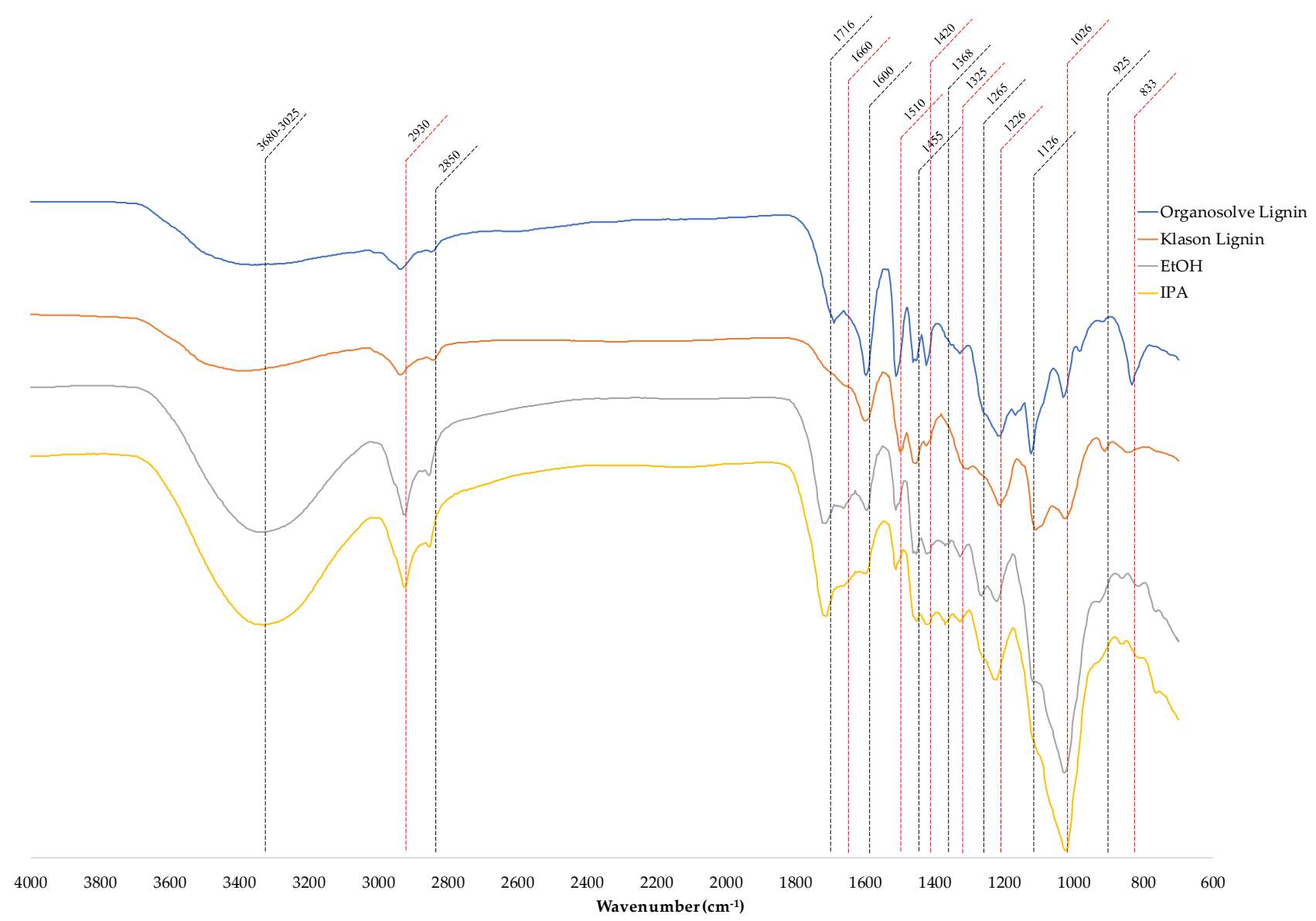

Figure 3. FT-IR spectra of lignin by organosolv, Klason, and solvent extraction with the microwaveassisted method. 
FT-IR results, the spectra of extracted lignins that are extracted by isopropanol and ethanol, had no significant difference. In addition, the Klason and organosolv method were not the same as the sample from this extraction. The board band at $3680-3025 \mathrm{~cm}^{-1}$ was the $\mathrm{O}-\mathrm{H}$ stretching vibration in the aliphatic and aromatic hydroxy groups. At $3680-3025 \mathrm{~cm}^{-1}$, the extracted lignin using isopropanol as solvent achieved higher relative intensities indicating the higher hydroxy group content in the solution. Moreover, the lignin from Klason and organosolv that used acid as a catalyst had lower oxidation compared with this method. The bands at $2930 \mathrm{~cm}^{-1}$ and $2850 \mathrm{~cm}^{-1}$ were $\mathrm{CH}$ stretch in the methyl and methylene group and $\mathrm{C}-\mathrm{H}$ stretch in $\mathrm{O}-\mathrm{CH}_{3}$ group, respectively. The peak at $1716 \mathrm{~cm}^{-1}$ was a $\mathrm{C}=\mathrm{O}$ stretch of unconjugated carboxyl, ketone, and ester groups, which could be used to investigate the lignin and remaining hemicellulose during the extraction [25,33]. The peak at $1660 \mathrm{~cm}^{-1}$ was assigned to the conjugated carbonyl stretching in lignin. The peaks at 1600, 1510, 1170, and $1420 \mathrm{~cm}^{-1}$ were aromatic skeletal vibrations, and the $\mathrm{C}-\mathrm{H}$ deformation frequencies combined with aromatic ring vibration at $1455 \mathrm{~cm}^{-1}$. The peaks in the Klason and organosolv lignin showed a clearer peak because these methods have precipitation of lignin in the water. In contrast, this method must be aware of moisture content in the solution. The phenolic hydroxyl group was represented by the absorbance at $1368 \mathrm{~cm}^{-1}$, which can be attributed to the breaking of $\beta-\mathrm{O}-4$ bonds during extraction. This band indicated that the microwave irritation not only broke the bond connecting lignin with cellulose and hemicellulose but also broke the ether bond in the lignin [34]. The peaks at 1265, 1226, and $833 \mathrm{~cm}^{-1}$ approached guaiacyl units. The guaiacyl (coniferyl alcohol) is the highest monomer content in lignin from rubberwood. The absorbance at 1325 and $1126 \mathrm{~cm}^{-1}$ was the syringyl ring breathing and C-O stretching. The absorbance at $1026 \mathrm{~cm}^{-1}$ was assigned to the $\mathrm{C}-\mathrm{O}-\mathrm{C}$ mode of the glycosidic linkages [33]. This absorbance at $1026 \mathrm{~cm}^{-1}$ indicated that glycosidic of cellulose and hemicellulose remained in the solution. At $925 \mathrm{~cm}^{-1}$ a pyranose ring in hemicellulose was indicated. The solutions from both solvent extractions were rich in phenolic, carbonyl, and aromatic compounds. The spectra identified that the samples were composed of lignin. However, the samples were contaminated with cellulose and hemicellulose that remained during extraction.

Table 1. Assignment of FT-IR bands $[25,33,35,36]$.

\begin{tabular}{|c|c|}
\hline Wavenumbers $\left(\mathrm{cm}^{-1}\right)$ & Assignments \\
\hline $3680-3025$ & O-H stretch, H-bonded \\
\hline 2930 & C-H stretch methyl and methylene groups (aliphatic) \\
\hline 2850 & $\mathrm{C}-\mathrm{H}$ stretch $\mathrm{O}-\mathrm{CH}_{3}$ group \\
\hline 1716 & $\mathrm{C}=\mathrm{O}$ stretch, unconjugated ketone, carboxyl, and ester groups \\
\hline 1660 & $\mathrm{C}=\mathrm{O}$ stretch conj. \\
\hline 1600 & Aromatic skeletal vibration \\
\hline 1510 & Aromatic skeletal vibration \\
\hline 1455 & $\mathrm{CH}$ deformations and aromatic ring vibrations \\
\hline 1420 & Aromatic skeletal vibration combined with $\mathrm{C}-\mathrm{H}$ in plane deformation \\
\hline 1368 & Phenolic hydroxyl group \\
\hline 1325 & Syringyl ring breathing, $\mathrm{C}-\mathrm{O}$ stretch \\
\hline 1265 & $\mathrm{C}-\mathrm{C}, \mathrm{C}-\mathrm{O}$, and $\mathrm{C}=\mathrm{O}$ stretches in guaiacyl \\
\hline 1226 & Guaiacyl ring breathing \\
\hline 1170 & Aromatic $\mathrm{C}-\mathrm{H}$ in plane deformation \\
\hline 1126 & Syringyl ring breathing \\
\hline 1026 & $\mathrm{C}-\mathrm{O}-\mathrm{C}$ \\
\hline 925 & C-H deformation of out of plane, aromatic ring, pyranose ring \\
\hline 833 & Aromatic $\mathrm{CH}$ out of plane deformation $\mathrm{G}+\mathrm{S}$ \\
\hline
\end{tabular}

\subsection{D HSQC NMR Analytical Method}

The two-dimensional ${ }^{13} \mathrm{C}-{ }^{1} \mathrm{H}$ HSQC association spectrum indicated carbons attached with protons, which is a useful method for understanding the lignin structure. The extracted lignins, Klason lignin, and organosolv lignin were subjected to 2D NMR analysis. The HSQC spectra showed a region corresponding to the side chain region. The side chain regions $\left(\delta_{C} 50-95 \mathrm{ppm}\right.$ and $\left.\delta_{\mathrm{H}} 2.0-5.5 \mathrm{ppm}\right)$ are shown in Figure 4. The main spectra were 
indicated in the HSQC spectra by comparison with previous literature data [37-39] and are exhibited in Table 2.

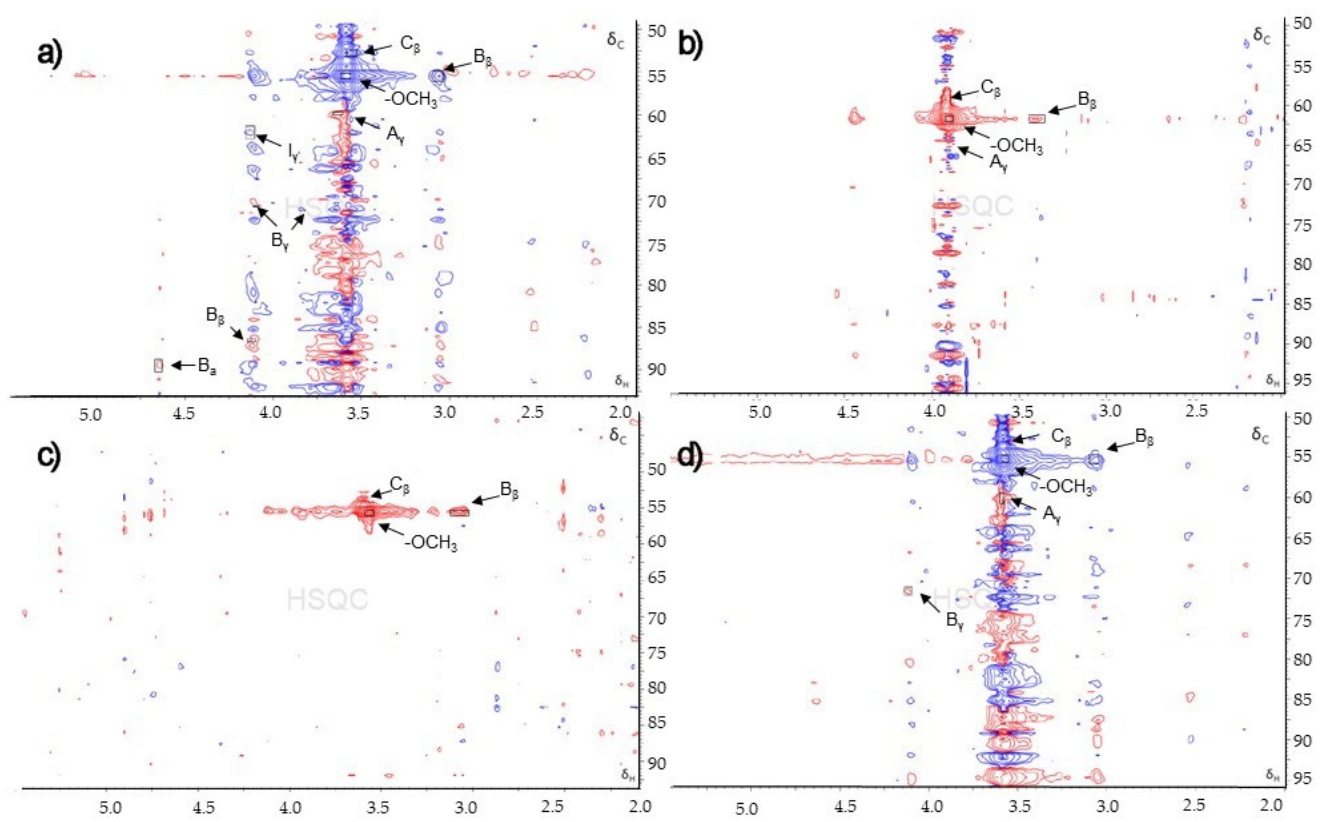

Figure 4. HSQC spectra $\left(\delta_{\mathrm{C}} / \delta_{\mathrm{H}} 50-95 / 2.0-5.5\right)$ of (a) solutions of extracted lignin by using ethanol, (b) solutions of extracted lignin using isopropanol, (c) Klason lignin, and (d) Organosolv lignin.

Table 2. Assignment of Main signals in the 2D HSQC NMR spectra of lignin [37].

\begin{tabular}{ccc}
\hline Labels & $\delta_{\mathrm{C}} / \delta_{\mathbf{H}}$ & Assignment \\
\hline $\mathrm{C}_{\beta}$ & $52.81 / 3.55$ & $\mathrm{C}_{\beta}-\mathrm{H}_{\beta}$ in phenylcoumaran substructures (C) \\
$\mathrm{B}_{\beta}$ & $55.48 / 3.06$ & $\mathrm{C}_{\beta}-\mathrm{H}_{\beta}$ in resinol substructures (B) \\
$-\mathrm{OCH}_{3}(\mathrm{OMe})$ & $55.48 / 3.58$ & $\mathrm{C}-\mathrm{H}$ in methoxyls \\
$\mathrm{A}_{\gamma}$ & $59.83 / 3.63$ & $\mathrm{C}_{\gamma}-\mathrm{H}_{\gamma}$ in $\beta-\mathrm{O}-4$ substructures (A) \\
$\mathrm{I}_{\gamma}$ & $62.08 / 4.13$ & $\mathrm{C}_{\gamma}-\mathrm{H}_{\gamma}$ in cinnamyl alcohol end- groups (I) \\
$\mathrm{B}_{\gamma}$ & $70.79 / 4.10,71.21 / 3.82$ & $\mathrm{C}_{\gamma}-\mathrm{H}_{\gamma}$ in resinol substructures (B) \\
$\mathrm{B}_{\mathrm{a}}$ & $89.47 / 4.65$ & $\mathrm{C}_{\mathrm{a}}-\mathrm{H}_{\mathrm{a}}$ in resinol substructures (B) \\
$\mathrm{A}_{\beta}$ & $86.52 / 4.12$ & $\mathrm{C}_{\beta}-\mathrm{H}_{\beta}$ in $\beta-\mathrm{O}-4$ substructures linked to a $\mathrm{S}$ unit (A) \\
\hline
\end{tabular}

The internal linkages in the lignin structure were present in the side chain region of the HSQC spectra. All of the lignin samples showed the most predominant, which was the methoxyls $\left(\delta_{C} / \delta_{H} 55.48 / 3.06\right)$ linkage. The resinol substructures $(B)$ were detected by their C-H correlation for $\mathrm{C}_{\beta}-\mathrm{H}_{\beta}, \mathrm{C}_{\gamma}-\mathrm{H}_{\gamma}$, and $\mathrm{C}_{\mathrm{a}}-\mathrm{H}_{\mathrm{a}}$ at $\delta_{\mathrm{C}} / \delta_{\mathrm{H}} 55.48 / 3.06,70.79 / 4.10$ \& $71.21 / 3.82$, and $89.47 / 4.65$. The extracted lignin using ethanol as solvent showed a high content of methoxyls and resinol substructure. $\beta-\mathrm{O}-4$ substructures $(\mathrm{A})$ were confirmed by $\mathrm{C}-\mathrm{H}$ correlations at $\delta_{\mathrm{C}} / \delta_{\mathrm{H}} 59.83 / 3.63$ and $86.52 / 4.12$ for $\mathrm{C}_{\gamma}-\mathrm{H}_{\gamma}$ and $\mathrm{C}_{\beta}-\mathrm{H}_{\beta}$. Phenylcoumaran substructures (C) and cinnamyl alcohol end-groups (I) presented some C-H correlation at $\delta_{C} / \delta_{\mathrm{H}} 52.81 / 3.55$ and $62.08 / 4.13$, respectively. However, all correlations were detected at a low contour level except methoxyls correlation, which had a strong spectrum. For this reason, it is difficult to indicate the $\mathrm{C}-\mathrm{H}$ correlation of the lignin structure due to a lot of undesired peaks.

\subsection{UV-Vis Analytical Method}

The UV spectra of products are shown in Figure 5. Lignin solutions presented UV spectra characteristic of lignin with the maximal peak at $280 \mathrm{~nm}$, which indicated the non-conjugated phenolic in lignin $[40,41]$. The Klason lignin was used for comparing with the lignin solution from the experimental method. The extracted lignin solutions from both solvents showed a maximum peak at $280 \mathrm{~nm}$, the same as the Klason lignin. In addition, the absorbance of the extracted lignin by isopropanol was lower than ethanol as solvent at the 
same conditions. This result indicated the ethanol solvent had high extract efficiency. In the solution extracted by isopropanol, the absorbance at 208 indicated isopropanol absorption.

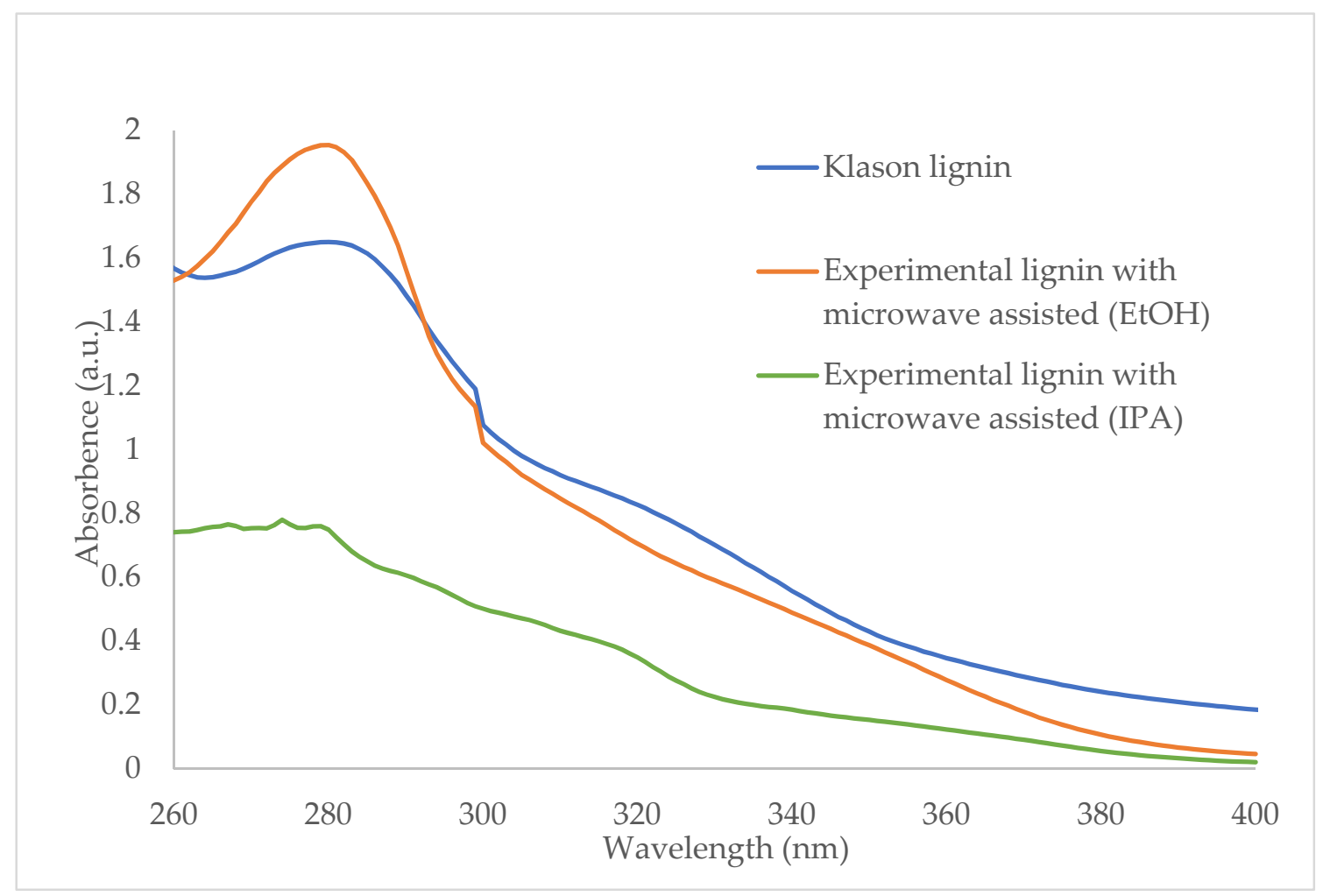

Figure 5. UV-visible spectra of experimental lignins and Klason lignin.

\subsection{HHV Characterization Method}

Figure 6 shows the HHV of the extracted solution compared with pure solvent (95.6\% $v / v$ ethanol and $99.8 \% v / v$ isopropanol). The extraction condition of solutions of extracted lignin was selected, which was optimized at a microwave power of $200 \mathrm{~W}$ and $30 \mathrm{~min}$. HHV of both solutions of extracted lignin were lower than the pure solvent. HHV of lignin $(17,000-25,000 \mathrm{~kJ} / \mathrm{kg}$ ) depends on the molecular weight of lignin [42]. In addition, the heating value of lignin was lower than the pure alcohol solvent. The results showed that the extracted lignin that contained lignin and alcohol had lower HHV than the pure alcohol solvent. The HHV of the solutions of extracted lignin by using ethanol as a solvent was less than $9.86 \%$ compared with ethanol $95 \%$. The HHV of the solutions of extracted lignin by using isopropanol as a solvent was less than $1.13 \%$ compared with isopropanol. Several works have used lignin as an additive in transport fuel $[43,44]$. The extracted solution could be an additive in gasoline and/or diesel rich of in hydroxyl, phenolic, carbonyl, and aromatic compounds. However, this extracted lignin must be tested for quality and performance, such as combustion performance tests, engine efficiency tests, emission tests, etc. 


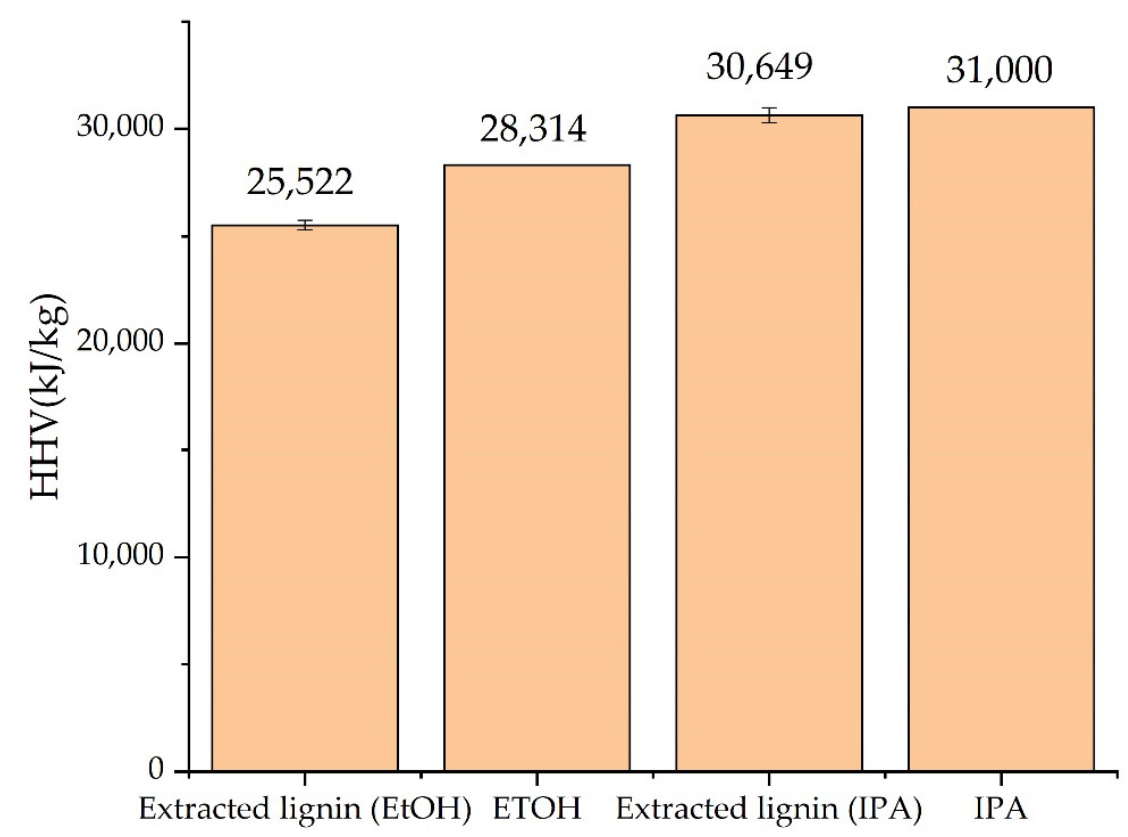

Figure 6. HHV of solutions of the extracted lignins and their solvent.

\section{Conclusions}

The objective of this research was to investigate lignin extraction using a solvent extraction method with a microwave-assisted method. According to the results, ethanol extraction was more effective than isopropanol in terms of lignin solubility. With increasing microwave operating time and power, the yield of extracted lignin recovery improved. At $200 \mathrm{~W}$ for $30 \mathrm{~min}$ and ethanol as the solvent, the highest lignin recovery yield was 6.26 percent. The link between lignin and cellulose and hemicellulose was broken by microwave irritation. Microwave breaks the ether link that connects the lignin monomer. Furthermore, because this technique did not involve lignin precipitation in water, the extracted lignin was contaminated with hemicellulose and cellulose. Because lignin has a low heating value, the heating value of the extracted solutions was lower than that of the pure solvent. The extracted solution could be an additive in fuel rich in hydroxyl, phenolic, carbonyl, and aromatic compounds.

Author Contributions: Conceptualization, N.L.; Investigation, T.Y.; Methodology, T.Y. and N.L.; Project administration, N.L.; Supervision, N.L.; Writing—original draft, T.Y.; Writing—review \& editing, W.K., W.-C.L. and N.L. All authors have read and agreed to the published version of the manuscript.

Funding: This research received no external funding.

Institutional Review Board Statement: Not applicable.

Informed Consent Statement: Not applicable.

Data Availability Statement: Not applicable.

Acknowledgments: We would like to thank the department of Chemical Engineering, Faculty of Engineering, King Mongkut's Institute of Technology Ladkrabang, Thailand, for supporting research facilities.

Conflicts of Interest: The authors declare no conflict of interest.

\section{References}

1. Somerville, C.; Youngs, H.; Taylor, C.; Davis, S.C.; Long, S.P. Feedstocks for Lignocellulosic Biofuels. Science 2010, 329, 790-792. [CrossRef] [PubMed]

2. Yang, D.; Qiu, X.; Zhou, M.; Lou, H. Properties of Sodium Lignosulfonate as Dispersant of Coal Water Slurry. Energy Convers. Manag. 2007, 48, 2433-2438. [CrossRef] 
3. Yang, D.; Qiu, X.; Pang, Y.; Zhou, M. Physicochemical Properties of Calcium Lignosulfonate with Different Molecular Weights as Dispersant in Aqueous Suspension. J. Dispers. Sci. Technol. 2008, 29, 1296-1303. [CrossRef]

4. Milczarek, G. Kraft Lignin as Dispersing Agent for Carbon Nanotubes. J. Electroanal. Chem. 2010, 638, 178-181. [CrossRef]

5. El-Khatib, E.M.; Ali, N.F.; Nassar, S.H.; El-Shemy, N.S. Functionalization of Natural Fibers Properties by Using Tio 2 Nanoparticles to Improve Its Antimicrobial Activity. Biointerface Res. Appl. Chem. 2022, 12, 4177-4191. [CrossRef]

6. Zimniewska, M.; Kozłowski, R.; Batog, J. Nanolignin Modified Linen Fabric as a Multifunctional Product. Mol. Cryst. Liq. Cryst. 2008, 484, 43-50. [CrossRef]

7. Chung, Y.-L.; Olsson, J.V.; Li, R.J.; Frank, C.W.; Waymouth, R.M.; Billington, S.L.; Sattely, E.S. A Renewable Lignin-Lactide Copolymer and Application in Biobased Composites. ACS Sustain. Chem. Eng. 2013, 1, 1231-1238. [CrossRef]

8. Xue, B.L.; Wen, J.L.; Sun, R.C. Lignin-Based Rigid Polyurethane Foam Reinforced with Pulp Fiber: Synthesis and Characterization. ACS Sustain. Chem. Eng. 2014, 2, 1474-1480. [CrossRef]

9. Del Saz-Orozco, B.; Oliet, M.; Alonso, M.V.; Rojo, E.; Rodríguez, F. Formulation Optimization of Unreinforced and Lignin Nanoparticle-Reinforced Phenolic Foams Using an Analysis of Variance Approach. Compos. Sci. Technol. 2012, 72, 667-674. [CrossRef]

10. Yang, C.; Liu, P. Water-Dispersed Conductive Polypyrroles Doped with Lignosulfonate and the Weak Temperature Dependence of Electrical Conductivity. Ind. Eng. Chem. Res. 2009, 48, 9498-9503. [CrossRef]

11. Wang, R.; Jiao, L.; Zhou, X.; Guo, Z.; Bian, H.; Dai, H. Highly Fluorescent Graphene Quantum Dots from Biorefinery Waste for Tri-Channel Sensitive Detection of $\mathrm{Fe}^{3+}$ Ions. J. Hazard. Mater. 2021, 412, 125096. [CrossRef] [PubMed]

12. Norgren, M.; Edlund, H. Lignin: Recent Advances and Emerging Applications. Curr. Opin. Colloid Interface Sci. 2014, 19, 409-416. [CrossRef]

13. Tran, M.H.; Phan, D.P.; Nguyen, T.H.; Kim, H.B.; Kim, J.; Park, E.D.; Lee, E.Y. Catalytic Hydrogenolysis of Alkali Lignin in Supercritical Ethanol over Copper Monometallic Catalyst Supported on a Chromium-Based Metal-Organic Framework for the Efficient Production of Aromatic Monomers. Bioresour. Technol. 2021, 342, 125941. [CrossRef] [PubMed]

14. Kumar, A.; Biswas, B.; Kaur, R.; Krishna, B.B.; Bhaskar, T. Hydrothermal Oxidative Valorisation of Lignin into Functional Chemicals: A Review. Bioresour. Technol. 2021, 342, 126016. [CrossRef] [PubMed]

15. Hashmi, S.F.; Meriö-Talvio, H.; Ruuttunen, K.; Sixta, H. Influence of Reaction Conditions on Solvolysis of Organosolv Lignin Using Water and Green Organic Co-Solvents as Reaction Medium. Fuel Process. Technol. 2020, 197, 106200. [CrossRef]

16. Dong, M.; Wu, C.; Chen, L.; Zhou, X.; Yang, W.; Xiao, H.; Ji, X.; Dai, H.; Hu, C.; Bian, H. Benzenesulfonic Acid-Based Hydrotropic System for Achieving Lignocellulose Separation and Utilization under Mild Conditions. Bioresour. Technol. 2021, 337, 125379. [CrossRef] [PubMed]

17. Shi, Y.; Xia, X.; Li, J.; Wang, J.; Zhao, T.; Yang, H.; Jiang, J.; Jiang, X. Solvolysis Kinetics of Three Components of Biomass Using Polyhydric Alcohols as Solvents. Bioresour. Technol. 2016, 221, 102-110. [CrossRef]

18. Kumar, A.; Anushree; Kumar, J.; Bhaskar, T. Utilization of Lignin: A Sustainable and Eco-Friendly Approach. J. Energy Inst. 2020, 93, 235-271. [CrossRef]

19. Duan, D.; Wang, Y.; Ruan, R.; Tayier, M.; Dai, L.; Zhao, Y.; Zhou, Y.; Liu, Y. Comparative Study on Various Alcohols Solvolysis of Organosolv Lignin Using Microwave Energy: Physicochemical and Morphological Properties. Chem. Eng. Process. Process Intensif. 2018, 126, 38-44. [CrossRef]

20. Li, H.; Cai, X.; Wang, Z.; Xu, C. Cost-Effective Production of Organosolv Lignin from Woody Biomass Using Ethanol-Water Mixed Solvent at Mild Conditions. J. Supercrit. Fluids 2020, 158, 104745. [CrossRef]

21. Ahmad, E.; Pant, K.K. Lignin Conversion: A Key to the Concept of Lignocellulosic Biomass-Based Integrated Biorefinery. In Waste Biorefinery; Elsevier B.V.: Amsterdam, The Netherlands, 2018. [CrossRef]

22. Inkrod, C.; Raita, M.; Laosiripojana, N. Characteristics of Lignin Extracted from Pararubber Wood Sawdust via Organosolv Fractionation. J. Sustain. Energy Environ. 2017, 8, 71-76.

23. Bundhoo, Z.M.A. Microwave-Assisted Conversion of Biomass and Waste Materials to Biofuels. Renew. Sustain. Energy Rev. 2018, 82, 1149-1177. [CrossRef]

24. Yu, H.B.; Ding, L.F.; Wang, Z.; Shi, L.X. Study on Extraction of Polyphenol from Grape Peel Microwave-Assisted Activity. Adv. Mater. Res. 2014, 864-867, 520-525. [CrossRef]

25. Imman, S.; Arnthong, J.; Burapatana, V.; Champreda, V.; Laosiripojana, N. Fractionation of Rice Straw by a Single-Step Solvothermal Process: Effects of Solvents, Acid Promoters, and Microwave Treatment. Renew. Energy 2015, 83, 663-673. [CrossRef]

26. Zhou, L.; Budarin, V.; Fan, J.; Sloan, R.; Macquarrie, D. Efficient Method of Lignin Isolation Using Microwave-Assisted Acidolysis and Characterization of the Residual Lignin. ACS Sustain. Chem. Eng. 2017, 5, 3768-3774. [CrossRef]

27. Ninomiya, K.; Yamauchi, T.; Ogino, C.; Shimizu, N.; Takahashi, K. Microwave Pretreatment of Lignocellulosic Material in Cholinium Ionic Liquid for Efficient Enzymatic Saccharification. Biochem. Eng. J. 2014, 90, 90-95. [CrossRef]

28. Tappi. Acid-Insoluble Lignin in Wood and Pulp (Reaffirmation of T 222 Om-06); Tappi: Atlanta, GA, USA, 2011 ; pp. 1-7.

29. Rodríguez, A.; Espinosa, E.; Domínguez-Robles, J.; Sánchez, R.; Bascón, I.; Rosal, A. Different Solvents for Organosolv Pulping. In Pulp and Paper Processing; Kazi, M.S.N., Ed.; Intech Open: London, UK, 2018. [CrossRef]

30. Links, D.A.; Xu, J.; Jiang, J.; Hse, C.; Shupe, T.F. Renewable Chemical Feedstocks from Integrated Liquefaction Processing of Lignocellulosic Materials Using Microwave Energy. Green Chem. 2012, 14, 2821-2830. [CrossRef] 
31. Chemat, F.; Esveld, E. Microwave Super-Heated Boiling of Organic Liquids: Oigin, Effect and Application. Chem. Eng. Technol. 2001, 24, 735-744. [CrossRef]

32. Kohli, K.; Katuwal, S.; Biswas, A.; Sharma, B.K. Effective Delignification of Lignocellulosic Biomass by Microwave Assisted Deep Eutectic Solvents. Bioresour. Technol. 2020, 303, 122897. [CrossRef]

33. El Hage, R.; Brosse, N.; Chrusciel, L.; Sanchez, C.; Sannigrahi, P.; Ragauskas, A. Characterization of Milled Wood Lignin and Ethanol Organosolv Lignin from Miscanthus. Polym. Degrad. Stab. 2009, 94, 1632-1638. [CrossRef]

34. Muley, P.D.; Mobley, J.K.; Tong, X.; Novak, B.; Stevens, J.; Moldovan, D.; Shi, J.; Boldor, D. Rapid Microwave-Assisted Biomass Delignification and Lignin Depolymerization in Deep Eutectic Solvent. Energy Convers. Manag. 2019, 196, 1080-1088. [CrossRef]

35. Mansor, A.M.; Lim, J.S.; Ani, F.N.; Hashim, H.; Ho, W.S. Characteristics of Cellulose, Hemicellulose and Lignin of MD2 Pineapple Biomass. Chem. Eng. Trans. 2019, 72, 79-84. [CrossRef]

36. Guerra, A.; Mendonca, R.; Ferraz, A.; Lu, F.; Ralph, J. Structural Characterization of Lignin during Pinus Taeda Wood Treatment with Ceriporiopsis Subvermispora. Appl. Environ. Microbiol. 2004, 70, 4073-4078. [CrossRef] [PubMed]

37. Huang, C.; He, J.; Narron, R.; Wang, Y.; Yong, Q. Characterization of Kraft Lignin Fractions Obtained by Sequential Ultrafiltration and Their Potential Application as a Biobased Component in Blends with Polyethylene. ACS Sustain. Chem. Eng. 2017, 5, 11770-11779. [CrossRef]

38. Yuan, T.Q.; Sun, S.N.; Xu, F.; Sun, R.C. Characterization of Lignin Structures and Lignin-Carbohydrate Complex (LCC) Linkages by Quantitative 13C and 2D HSQC NMR Spectroscopy. J. Agric. Food Chem. 2011, 59, 10604-10614. [CrossRef]

39. Bauer, S.; Sorek, H.; Mitchell, V.D.; Ibáñez, A.B.; Wemmer, D.E. Characterization of Miscanthus Giganteus Lignin Isolated by Ethanol Organosolv Process under Reflux Condition. J. Agric. Food Chem. 2012, 60, 8203-8212. [CrossRef] [PubMed]

40. Lin, S.Y.; Dence, C.W. (Eds.) Methods in Lignin Chemistry, 1st ed.; Springer: Berlin/Heidelberg, Germany, 1992. [CrossRef]

41. Lee, R.A.; Bédard, C.; Berberi, V.; Beauchet, R.; Lavoie, J.M. UV-Vis as Quantification Tool for Solubilized Lignin Following a Single-Shot Steam Process. Bioresour. Technol. 2013, 144, 658-663. [CrossRef]

42. Araújo, L.C.P.; Yamaji, F.M.; Lima, V.H.; Botaro, V.R. Kraft Lignin Fractionation by Organic Solvents: Correlation between Molar Mass and Higher Heating Value. Bioresour. Technol. 2020, 314, 123757. [CrossRef]

43. Zhou, L.; Boot, M.D.; Johansson, B.H.; Reijnders, J.J.E. Performance of Lignin Derived Aromatic Oxygenates in a Heavy-Duty Diesel Engine. Fuel 2014, 115, 469-478. [CrossRef]

44. Zhou, L.; Boot, M.D.; Johansson, B.H. Comparison of Emissions and Performance between Saturated Cyclic Oxygenates and Aromatics in a Heavy-Duty Diesel Engine. Fuel 2013, 113, 239-247. [CrossRef] 